\title{
The influence of body morphology on changes in core temperature during exercise in an uncompensable environment
}

\author{
Nicholas Ravanelli ${ }^{1}$, Matthew Cramer ${ }^{1}$, Pascal Imbeault ${ }^{1}$, Ollie Jay ${ }^{1,2^{*}}$ \\ From 15th International Conference on Environmental Ergonomics (ICEE XV) \\ Portsmouth, UK. 28 June - 3 July 2015
}

\section{Introduction}

Evidence demonstrates that for unbiased comparisons of changes in core temperature $\left(\Delta \mathrm{T}_{\text {core }}\right)$ between groups unmatched for body morphology, exercise should be performed using a fixed heat production $\left(\mathrm{H}_{\text {prod }}\right)$ per unit mass in physiologically compensable environments [1]. In uncompensable conditions, it has been suggested that a fixed external workload is the primary determinant of $\Delta \mathrm{T}_{\text {core }}$ [2], however in addition to not accounting for differences in $\mathrm{H}_{\text {prod }}$ relative to mass, such an approach excludes the influence of differences the surface area-to-mass ratio on the absolute maximum rate of evaporative heat loss $\left(E_{\max }\right)$. We examined the best method for performing unbiased comparisons of $\Delta \mathrm{T}_{\text {core }}$ between groups unmatched for body morphology during exercise in an uncompensable environment.

\section{Methods}

Six small (mean(SD) SM: 64.4(7.2) kg, $1.78(0.10) \mathrm{m}^{2}$, $276(21) \mathrm{cm}^{2} \cdot \mathrm{kg}^{-1}$ ) and four large (LG: $94.2(7.2) \mathrm{kg}$, $\left.2.19(0.09) \mathrm{m}^{2}, 233(8) \mathrm{cm}^{2} \cdot \mathrm{kg}^{-1}\right)$ participants were recruited. $E_{\max }$ for each participant was first assessed [3]. Participants then completed three trials, during which they cycled for $75 \mathrm{~min}$ at $35{ }^{\circ} \mathrm{C}, 70 \% \mathrm{RH}$, at a target (i) absolute workload of $100 \mathrm{~W}$, (ii) $\mathrm{H}_{\text {prod }}$ of $6 \mathrm{~W} \cdot \mathrm{kg}^{-1}$, or (iii) $\mathrm{H}_{\text {prod }}$ of $3 \mathrm{~W} \cdot \mathrm{kg}^{-1}$ above $\mathrm{E}_{\max }$.

\section{Results}

$\mathrm{E}_{\max }$ at $35{ }^{\circ} \mathrm{C}, 70 \% \mathrm{RH}$ was similar between SM and LG in W.m ${ }^{-2}\left(167\right.$ [27] vs. 146 [9] W.m $\left.{ }^{-2}\right)$, but lower in LG in W/kg (3.4 (0.2) vs. $\left.4.6(0.1) \mathrm{W}^{\mathrm{kg}} \mathrm{kg}^{-1}\right)$ by virtue of a difference in surface area-to-mass ratio. A systematically greater $\Delta \mathrm{T}_{\mathrm{re}}$ was observed in the SM group at an exter-

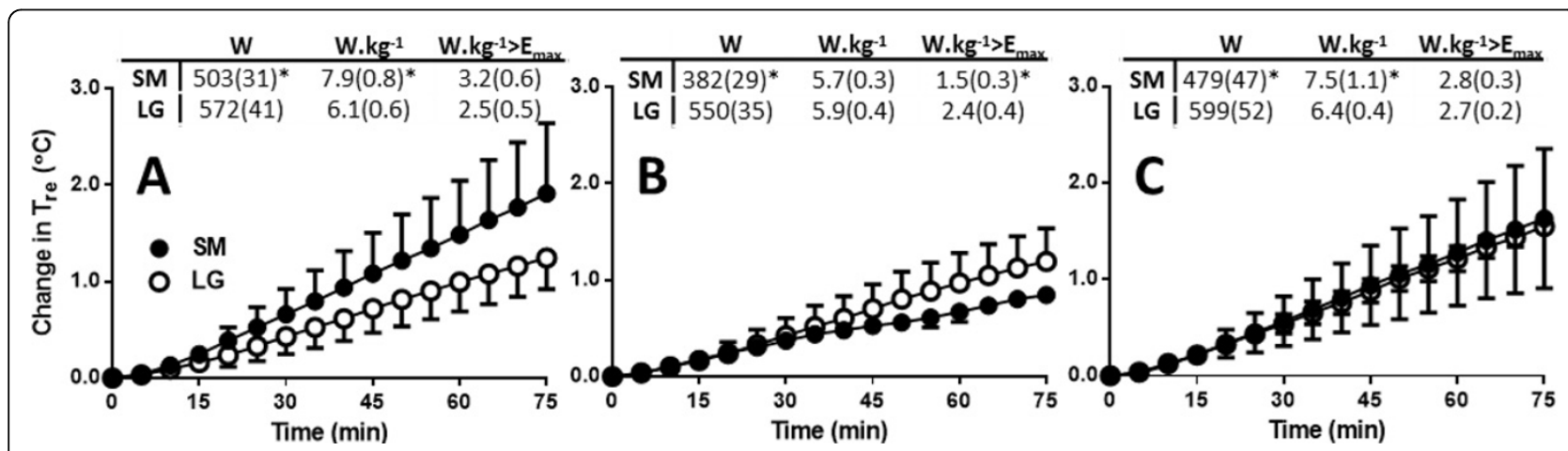

Figure 1 The change in rectal temperature (Tre) during exercise at a fixed: external workload of 100 W (A), Hprod of 6 W.kg-1 (B), and Hprod of 3 W.kg-1 above Emax (C). SM small; LG large. *Significantly different between groups within condition $(P<0.05)$.

* Correspondence: Ollie.jay@sydney.edu.au

'School of Human Kinetics, University of Ottawa, Canada

Full list of author information is available at the end of the article 
nal workload of $100 \mathrm{~W}(\mathrm{P}=0.036$; Figure $1 \mathrm{~A})$; and in the LG group at an $\mathrm{H}_{\text {prod }}$ of $6 \mathrm{~W} \cdot \mathrm{kg}^{-1}(\mathrm{P}<0.001$; Figure $1 \mathrm{~B})$. This systematic difference in $\Delta \mathrm{T}_{\text {re }}$ between SM and LG groups was abolished at a fixed $\mathrm{H}_{\text {prod }}$ of $3 \mathrm{~W} \cdot \mathrm{kg}^{-1}$ above $\mathrm{E}_{\max }(\mathrm{P}=0.999$; Figure $1 \mathrm{C})$.

\section{Discussion}

Theoretically, $\Delta \mathrm{T}_{\mathrm{re}}$ in an uncompensable environment should be determined by the rate of heat storage per unit mass, which is presently expressed as the difference between $\mathrm{H}_{\text {prod }}$ and $E_{\max }$ in W. $\mathrm{kg}^{-1}$. At a fixed absolute workload of $100 \mathrm{~W}, \Delta \mathrm{T}_{\mathrm{re}}$ and $\mathrm{H}_{\text {prod }}-\mathrm{E}_{\max }$ in W. $\mathrm{kg}^{-1}$ were greater in SM. At a fixed $H_{\text {prod }}$ of $6 \mathrm{~W} \cdot \mathrm{kg}^{-1}, \Delta \mathrm{T}_{\text {re }}$ and $\mathrm{H}_{\text {prod }}-\mathrm{E}_{\max }$ in W. $\mathrm{kg}^{-1}$ as greater in LG due to a smaller surface area-to-mass ratio. When $\mathrm{H}_{\text {prod }}-\mathrm{E}_{\max }$ in W. $\mathrm{kg}^{-1}$ was fixed between SM and LG, $\Delta \mathrm{T}_{\text {re }}$ was the same despite a different $\mathrm{H}_{\text {prod }}$ in W. $\mathrm{kg}^{-1}$.

\section{Conclusion}

Preliminary results suggest that over a fixed exercise duration in an uncompensable environment, unbiased comparisons of $\Delta \mathrm{T}_{\mathrm{re}}$ between groups/individuals of different body size (mass and BSA) may be best attained using an exercise intensity at a fixed $\mathrm{H}_{\text {prod }}-\mathrm{E}_{\max }$ in W. $\mathrm{kg}^{-1}$.

\section{Authors' details}

${ }^{1}$ School of Human Kinetics, University of Ottawa, Canada. ${ }^{2}$ Thermal Ergonomics Laboratory, Faculty of Health Sciences, University of Sydney, Australia.

Published: 14 September 2015

\section{References}

1. Cramer MN, Jay O: J Appl Physiol 2014, 116:1123-1132.

2. Mora-Rodriguez : Exerc Sport Sci Rev 2012, 40(2):79-87.

3. Kenney WL, Zeman MJ: J Appl Physiol 2002, 92:2256-2263.

doi:10.1186/2046-7648-4-S1-A143

Cite this article as: Ravanelli et al:: The influence of body morphology on changes in core temperature during exercise in an uncompensable environment. Extreme Physiology \& Medicine 2015 4(Suppl 1):A143.

\section{Submit your next manuscript to BioMed Central} and take full advantage of:

- Convenient online submission

- Thorough peer review

- No space constraints or color figure charges

- Immediate publication on acceptance

- Inclusion in PubMed, CAS, Scopus and Google Scholar

- Research which is freely available for redistribution

Submit your manuscript at www.biomedcentral.com/submit 